gain and this should be seriously considered where quarantine measures are framed. From a practical standpoint the writer does not hesitate to say that if state quarantines are to be effective, the closest coöperation between affected states must be established, and their effect on well established lines of commerce be seriously considered before they are promulgated.

\title{
CONTROL OF THE VARIEGATED CUTWORM IN VENTURA COUNTY, CALIFORNIA ${ }^{1}$
}

By G. E. Bensex, Collaborator, Truck Crop and Stored Product Insect Investigations, U. S. Dept. of Agriculture

\section{RECENT INJURY}

The variegated cutworm (Peridroma margaritosa (saucia) Hübn.) is widely distributed in Ventura County, California, and has done considerable damage in the last year (1914) to the sugar beet crop. The first serious outbreak occurred in April, 1913, when about three hundred acres of young beets were cut off just beneath the surface of the ground. These dark brown "worms" were observed concealing themselves an inch or two underground during the day time, where in a dormant stage near the attacked plants they were ready to emerge on the return of night. It was also noticed that they generally followed the rows of beets, that very few fed during the day and that most of the damage was done during the night and early morning. The depredation is completed in so short a time that only preventive remedies could be recommended. The entire field was destroyed in less than four days. This field was summer-fallowed the previous year and the last generation evidently had deposited their eggs on the volunteer vegetation and this outbreak was the result of overwintering larvæ. This field was replanted but the cutworms destroyed the stand. It was then decided to postpone the second replanting with the object in mind that possibly the cutworms would, in the meantime, mature, enter the earth, and pupate. This supposition proved true and the third stand was unmolested. Unfortunately a second serious outbreak occurred in the same field about six weeks later. This time large beets were attacked and completely stripped. Only the stems were left untouched; even the roots were considerably damaged. The cutworms eat more ravenously during cool and foggy weather; hot sunshine checks to a large extent their ravages. The yield of the affected field was considerably reduced and very likely the sugar content of the beet was also materially reduced, as the elaboration of the sugar occurs in the leaves, which were largely damaged.

\footnotetext{
1 Published by permission of the Secretary, U. S. Dept. of Agriculture.
} 


\section{Natural Enemies}

Among natural enemies observed were two species of Calosoma, semilaeve Lec. and cancellatum Esch. which contributed to the destruction of this cutworm. Although predaceous insects and parasitesamong which the Ichneumonidæ must be mentioned ${ }^{1}$-destroy annually a great number of cutworms, practical remedies must be found to help these natural enemies in the control of this pest.

\section{Methods of Control}

In some cases rolling a young stand of beets has been very successful; in other cases no benefit was derived from this operation. If the stand of beets is completely destroyed or not worth saving, the cheapest and best way is to replant the crop, but at least three to four weeks must elapse between the two plantings. Local conditions must, naturally, be taken into consideration. In the season of 1914 no damage by cutworms to young beets was reported. April 20 was the date of the first outbreak on beets. These already had large foliage upon which spraying with arsenicals was tested.

\section{Control by Gasoline Power-Sprayer}

A gasoline power sprayer provided with a fifty-gallon barrel and one horsepower gasoline engine capable of maintaining while spraying a pressure of about one hundred and twenty pounds was used. This outfit was mounted on a light wagon with adjustable axles in order to circulate between sixteen and eighteen-inch rows of beets. Two men were required to handle the spraying outfit; one to drive and the other to attend the pump, watch the nozzles and prepare the mixture. The poison was applied at the rate of two pounds of Paris green to fifty gallons of water with the addition of one pound of molasses in order to render the solution more adhesive. Two or even three applications were required to check the work of the cutworms and these applications were made at an interval of four days. After the second application, the voracity of the cutworms decreased considerably. This device covered four rows of beets and sprayed about ten acres of beets in a day at the following cost:

Depreciation of apparatus................................. \$0.35

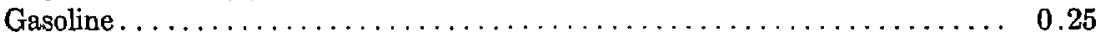

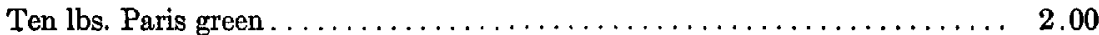

Two horses and two men $\ldots \ldots \ldots \ldots \ldots \ldots \ldots \ldots \ldots \ldots \ldots \ldots, 6.50$

$\$ 9.10$

This is approximately $\$ 0.90$ per acre for each application.

\footnotetext{
${ }^{1}$ One of the species reared is Enicospilus purgatus Say.
} 


\section{Control by Dry Paris Green}

The dry application of Paris green by means of a special arrangement on the ordinary horse cultivator was also tested. This method apparently gives a more uneven distribution of the Paris green but has the advantage of giving an extra cultivation to the suffering beets which undoubtedly stimulates their growth and thus increases the resistance of the weakened plants. The dry application was made early in the morning while the leaves were still damp in order to cause the poison to adhere better to the foliage. The tops of the sprayed beets were fed to cattle during the summer and no bad effects were reported.

\section{Ditching}

The writer also recommends that around the adjoining fields a ditch about one and one-half feet deep should be plowed as the cutworms are known, under certain conditions, to acquire the marching habit although this has never occurred so far in this locality. The ditch should be constructed with steep sides so that the cutworms cannot climb out and are obliged to travel along the bottom of the ditch and gather in holes placed along the bottom about forty feet apart.

\section{Trapping. Moths by Lights}

Besides the above-mentioned remedies another preventive remedy was tried which has been used on a large scale in Germany and Russiathe trapping of the adults or moths by means of light traps. In the various infested districts eight large electric arc lamps of 3,000 candle power each were installed, burning four kilowatt-hours a night of nine hours at a cost of approximately thirty cents a night. In the districts where no electric current was available a Milburn portable $500 \mathrm{C}$. P. acetylene gas light consuming about ten pounds calcium carbide at five cents a pound, or fifty cents a night, was used. Underneath these lights and at a distance of about ten inches a shallow galvanized iron pan four feet in diameter is set on a wood platform six feet above the ground. This pan contains water covered with a light coat of oil. The moths captured were counted every morning and a total of 96,046 moths were captured by the Arnold Dump trap light. All the electric light traps were placed upon the platforms of the sugarbeet unloading dumps which are about twelve feet above the ground. The 96,046 moths were caught during thirty-six nights at a cost of $\$ 17.28$ (144 kilowatt hours at twelve cents) or approximately at a cost of twenty cents a thousand. The number of moths captured varies greatly with the weather conditions at night. An essential condition for success is that the night should be warm, quiet and dark. During 
periods of drought or fogs the moths are difficult to capture. Besides the eight large lights, twenty-four small light traps were installed by individual farmers. These small lights captured about one thousand moths during a favorable night. The total number of moths captured reached the phenomenal figure of $1,000,000$ during the season of 1914 at a cost not exceeding twenty-five cents a thousand.

Many entomologists consider this method impractical, claiming that the females are captured after having deposited their eggs and that oviposition occurs immediately after the issuance of the moth. There is no doubt that the traps yield more males than females and that a large portion of females have already oviposited but the writer does not believe that the eggs are deposited immediately after the emergence. Copulation usually takes place very shortly after the appearance of the moths and the writer believes that several days may elapse after the moths appear before all of the eggs are laid. Mr. J. E. Graf, of the Bureau of Entomology, examined last year many captured moths and found that about 22 per cent were gravid females.

To sum up, the writer's experience shows that the treatment herein mentioned is worth the slight expense and although it cannot entirely control the cutworm plague it has extensively contributed to that end.

\section{PARASITISM AMONG THE LARVAE OF THE MEDITERRANEAN FRUIT-FLY (C. CAPITATA) IN HAWAII DURING I9I5}

\section{By E. A. Back and C. E. Pemberton, Bureau of Entomology}

Entomologists interested in the control of insect pests by natural agencies are already aware of the most excellent results obtained in the Hawaiian Islands from the introduction of parasites of the sugar cane leaf hopper (Perkinsiella saccharicida) and of the sugar cane borer (Rhabdocnemis obscurus). They will therefore follow with unusual interest the progress made by the parasites of the Mediterranean fruit-fly (Ceratitis capitata) introduced by Messrs. F. Silvestri, D. T. Fullaway and J. C. Bridwell from Africa and Australia under the auspices of the Hawaiian Board of Agriculture and Forestry.

The Mediterranean fruit-fly, since its introduction at Honolulu from Australia about 1910, has spread to all the important islands of the Hawaiian group, and, because of the great variety of its host fruits, an equitable climate, and peculiar physical conditions of the country, has not only seriously checked the horticultural development of the Islands, but has succeeded in withstanding all attempts directed at its control by artificial measures. 